\title{
12
}

\section{Separated Families and Child Support Policies in Times of Social Change: A Comparative Analysis}

\author{
Christine Skinner and Mia Hakovirta
}

Child support policies are designed to ensure that following family breakdown, parents in separated families continue to pay for the upkeep of their children until they reach adulthood. This obligation is enshrined within the United Nations Convention on the Rights of the Child (UNCRC). Article 27 (4) stipulates that:

State Parties shall take all appropriate measures to secure the recovery of maintenance for the child from the parents or other persons having financial responsibility for that child.

Article 27 therefore, sets out a moral and legal expectation for parents to ensure they cannot abrogate their financial responsibility to children on separation, but also for states to ensure separated parents continue to fulfill their responsibilities. This is a laudable aim and in practice, child support policies (or child maintenance policies) also try to reduce poverty, especially among single parent families following relationship breakdown. Child support refers to a cash sum to be paid regularly for the upkeep of children. Normally it is

C. Skinner

University of York, York, UK

e-mail: christine.skinner@york.ac.uk

M. Hakovirta $(\bowtie)$

University of Turku, Turku, Finland

e-mail: miahak@utu.fi 
paid by one parent to the other and is separate from any spousal or matrimonial support. In some countries with guaranteed child support schemes, the state may pay an advanced amount of child support claiming it back later from the other parent if appropriate (Skinner, Bradshaw, \& Davidson, 2007).

Previous comparative research on child support policies endeavored to: map out the different institutional arrangements and ways policy operates (Corden, 1999; Skinner et al., 2007; Skinner, Hakovirta, \& Davidson, 2012); how policies have developed historically in legal and moral terms (Wikeley, 2006); and more recently, how they have handled complex families and shared care arrangements (Claessens \& Mortelmans, 2018; Hakovirta \& Skinner, 2021). We argue in this chapter that it is important to examine social change and explore whether child support systems are adapting to changing family arrangements. Child support systems sit at the very fulcrum of change at a time when obligations to kin are questioned, adapted, rejected, or renewed by separated parents during the process of family breakdown. Yet social policy often struggles to keep up with changing family patterns (Meyer \& Carlson, 2014) and in some countries (UK for example) policy makers have failed to recognize how changes in social norms affect the rates of compliance with child support payments (Andrews, Armstrong, McLernon, Megaw, \& Skinner, 2011).

In this chapter, we first provide an overview of child support systems in 15 European countries drawing on a novel set of data. Second, we explore changes in child support systems with respect to gender equality and children's rights; whether societal changes in these domains are reflected in child support systems. This chapter draws from an international comparative study on child support systems from fifteen countries (two of which are regions within counties), Australia, Belgium, Denmark, Estonia, Finland, France, Germany, Iceland, New Zealand, Norway, Poland, Spain (Catalonia region), Sweden, United Kingdom (UK), and the United States (US, state of Wisconsin). We analyze the responses of national informants to a standardized questionnaire, which among other things, provides information on the policy objectives underpinning child support systems; the key operational features; how child support amounts are calculated and any changes in policy approach since 2006. We focus our analysis using a mixture of informants' accounts about the policy principles and whether informants explicitly mention gender equality as being an important component, alongside their reports on whether paternal/shared care and mothers' earnings were important aspects of their systems and featured in policy changes over time.

The structure of the chapter begins with a review of evidence outlining the key social changes which reflect a more gender equal division of paid work 
and care responsibilities in families. This sets the context to the study using the extant literature. We then describe the international study and explain the national informant method before moving onto our findings. First, the findings provide an up-to-date overview of the different types of child support systems and how they determine child support obligations from new research data collected in 2017. Second, we present our analysis of the national informants' reports on the main policy principles in their child support systems and consider any changes since 2006. We use that time frame in order to update and extend the earlier comparative study of 14 countries provided by Skinner and colleagues (2007). It used the same informant method and covered broadly similar aspects of child support systems as we do here in 2017.

\section{Social Change Reflecting Gender Equality}

Research studies assessing gender equality commonly use a number of quantitative measures including: female and male employment rates and earnings; engagement in different occupation sectors; time spent caring (for children and other relatives); and time spent doing domestic labor in the home. We make no attempt to discuss gender equality in these broad terms, other than to note that despite increasing rates of female employment, women are still subject to a gender pay gap (OECD, 2019). Rather, we aim to set the context to this chapter by focusing on key features of gender equality specifically in regard to parental responsibility: that is mothers' participation in employment and the division of labor in intact families.

\section{Maternal Employment}

It is well known that maternal employment rates have increased consistently in most developed countries. Looking at the latest data from the OECD, around $66 \%$ of mothers with children aged 0-14 were in employment in 2014, but rates differ considerably across countries (OECD, 2019). Looking at the 15 countries we focus on in this chapter, for five of them (Belgium, Denmark, Finland, France, and Sweden) more than $70 \%$ of mothers with children aged $0-14$ were in work, with rates being particularly highat around 82-83\% - in Denmark and Sweden. By contrast, in Australia, Estonia, Germany, New Zealand, Poland, Spain, UK, and U.S. employment rates for mothers with children aged $0-14$ were between 60 and $65 \%$. For Norway there was no data. 
Employment rates also differ by partnership status. A comparison of employment rates by different partnership status shows that in 2014 single mothers were employed about ten or more percentage points lower than partnered mothers in Australia, Belgium, Denmark, New Zealand, Sweden, and the UK. Whereas in Estonia and the US the employment rates for single mothers were higher than for partnered mothers. In the remainder of our comparison countries, employment rates for single mothers were only slightly lower than partnered mothers, ranging from $65 \%$ employment rate for single mothers in Finland to 58\% in Spain (OECD, 2019).

Overall, data from the OECD shows that in eight of our countries single mothers had higher employment rates than partnered mothers and in the remaining seven there were only slight differences (also see Chapter 9 by Adema, Clarke, \& Thévenon in this volume). On average therefore, single mothers' employment rates are on a par with partnered mothers or are slightly higher. However, maternal employment rates are only part of the story of social change in families. Understanding how change is manifest in terms of the division of labor between parents gives a different picture.

\section{Division of Labor}

In examining the division of labor, O'Connor (2013) conducted a comparative analysis of work and care responsibilities between parents showing these as "work-care models." These models provide information on the numbers of single earner families; dual earner-carer families and within that group, dual full-time earners and dual one-and-a-half earner families (where the latter is commonly a full-time male earner and part-time female earner). We have updated that analysis here using recent OECD data (2019) and have presented the results across our 15 countries organized by type of child support system shown in Table 12.1. This sets the context of the division of labor between parents in intact families comparatively for the 15 countries in our study.

Table 12.1 shows the percentage of children (aged 0-14) living in couple households by the employment status of adults in their household. Data are therefore presented from the child's perspective; they look at the proportion of children in a given household type with a given employment status. In most cases at least one member of the couple is one of the child's parents, but the adults may also be other relatives (an older sibling or grandparent) or non-relative guardians. The table presents a more nuanced picture than the simple OECD (2019) average of 50\% of children living in dual earner 
Table 12.1 Employment patterns among couple households with children aged 0-14, 2014 by type of child support system across 15 countries

\begin{tabular}{|c|c|c|c|c|c|}
\hline & $\begin{array}{l}\text { Dual earner } \\
\text { household- } \\
\text { two adults } \\
\text { working full } \\
\text { time } \\
\%\end{array}$ & $\begin{array}{l}\text { Dual earner } \\
\text { household- } \\
\text { one adult } \\
\text { working full } \\
\text { time, one } \\
\text { working part } \\
\text { time } \\
\%\end{array}$ & $\begin{array}{l}\text { Single earner } \\
\text { household- } \\
\text { one adult } \\
\text { working full } \\
\text { time } \\
\%\end{array}$ & $\begin{array}{l}\text { Working } \\
\text { household } \\
\text { *_other } \\
\text { arrangement } \\
\%\end{array}$ & $\begin{array}{l}\text { Workless } \\
\text { households-all } \\
\text { adults not } \\
\text { tworking } \\
\%\end{array}$ \\
\hline \multicolumn{6}{|c|}{ Agency-based child support systems } \\
\hline Australia & 19 & 38 & 31 & 6 & 6 \\
\hline Denmark & 68 & 11 & 16 & 2 & 3 \\
\hline $\begin{array}{l}\text { New } \\
\text { Zealand }\end{array}$ & - & - & - & - & - \\
\hline Norway & - & - & - & - & - \\
\hline $\begin{array}{l}\text { United } \\
\text { Kingdor }\end{array}$ & $m^{27}$ & 32 & 26 & 9 & 6 \\
\hline \multicolumn{6}{|c|}{ Court-based child support systems } \\
\hline Belgium & 45 & 21 & 21 & 5 & 7 \\
\hline Estonia & 46 & 9 & 38 & 3 & 4 \\
\hline France & 47 & 16 & 26 & 5 & 6 \\
\hline Germany & 22 & 39 & 29 & 4 & 5 \\
\hline Poland & 52 & 6 & 35 & 2 & 5 \\
\hline Spain & 38 & 13 & 32 & 8 & 8 \\
\hline \multicolumn{6}{|c|}{ Hybrid child support systems } \\
\hline Finland & 50 & 8 & 31 & 7 & 4 \\
\hline Iceland & - & - & - & - & - \\
\hline Sweden & 68 & 10 & 14 & 3 & 4 \\
\hline $\begin{array}{l}\text { United } \\
\text { States }\end{array}$ & $61 * *$ & - & 36 & - & 3 \\
\hline
\end{tabular}

*Captures all other types of working patterns, including where both adults are in part-time employment and single-earner households where one adult works parttime and the other does not work, plus any single or two earner households where information on one of the adults working hours is missing

**Data in the U.S. refers to children aged $0-17$ and no distinction is made between full-time and part-time work

Source OECD (2019). Family policy database. http://www.oecd.org/els/family/database. htm\#labour_market

households. It shows Denmark and Sweden are most characterized by fulltime dual earners followed by the US. In Poland and Finland about 50\% of children live in households where both parents work full-time. Percentages are slightly lower in France, Estonia, and Belgium. Australia, the UK, and Germany are characterized by one adult working full-time and the other adult working part-time, a one-and-a-half earner model. Yet, there is still a substantial minority of households where over a third of children live in more traditional male breadwinner households in Australia, Estonia, Poland, Spain, 
and the US. Only Sweden and Denmark have a very low percentage of children living in a single earner household (16 and 14\%, respectively). This, alongside their higher percentage of dual full-time earners, implies they have the greatest gender equality in employment between parents.

Despite the importance of the labor market however, the household is the central site in determining how the division of labor is organized in families. Such that changes in work patterns (i.e., increases in female employment rates) are closely interlinked with the sharing of housework and caring tasks between parents. We might expect therefore, that women spending more time in paid work would result in an equivalent rise in men's participation in domestic labor. On average however, while men and women's contributions have become more equal over time, this is because women are doing much less housework than hitherto, not because men are doing much more (Bianchi, 2011). On average men's contributions have increased only slightly.

Regarding childcare tasks a similar picture emerges: while fathers are spending more time on childcare activities, it is still not gender equal (OECD, 2019). We also know that historically for separated families, mothers have been the main resident parent and fathers have had a minor caring role which has been actualized by contact arrangements rather than resident arrangements. More recently however, evidence shows a growing number of separated parents do jointly care for their child(ren) either equally, or at least for 30\% of the time (Fehlberg, Smyth, Maclean, \& Roberts, 2011; Hakovirta \& Skinner, 2021; Smyth, 2017; Trinder, 2010). The practice of "joint physical custody" where a child spends equal time living with both parents and both parents have responsibility to physically care has also become a more popular arrangement in some countries. In most of the Nordic countries (except Finland), for example, 22-35\% of children have this kind of joint custody arrangement post-separation (Hakovirta \& Eydal, 2020). In contrast, in the UK, reports from a number of different surveys show that shared care prevalence ranges from 3 to $17 \%$. Notably however, some accounts from resident parents (commonly mothers) suggest that equal 50-50 time arrangements could be as low as 1\% (Haux, McKay, \& Cain, 2017). Currently the evidence presents a very mixed picture, partly because there is no common definition of what shared care or shared physical custody means making it difficult to measure comparatively (Hakovirta \& Skinner, 2021).

Measuring the amount of time spent by men and women doing various tasks has proved useful in understanding the division of labor in families, but there are many other explanations for these patterns which lie outside 
such measurement. This includes, among other things, the way heterosexual couples "do gender" and how gender borders become established in families (Lyonette \& Crompton, 2015). Research by Craig (2006a, 2006b) also shows that parenting as a mother is not the same as parenting as a father, even for women who work full-time in the paid labor force. The conditions of childcare appear to be harder for mothers: mothering involves more double activity, more physical labor, a more rigid timetable, and more overall responsibility than fathering.

A strong body of evidence therefore continues to grow. We highlight that here to show the structural and social changes in family practices in terms of the division of labor between parents but also to show the small but concomitant move toward greater gender equality (as measured by time spent doing different activities). These trends toward a more equal sharing of parenting responsibilities demonstrate a shift in social norms which vary by country and are influenced by many factors, including family policies. It is not the purpose of this chapter however, to offer any explanation of these influencing factors; rather the central concern here is to consider whether these changes are recognized in child support systems and to raise questions about the possible implications. Certainly, the traditional breadwinning family is no longer common in many countries, making it harder for child support systems to decide how best to allocate economic responsibility between separated parents. This analysis will explore how child support systems might recognize gender equality in the sharing of work and care in separated families using new data on child support systems across 15 countries (which includes two regions: the state of Wisconsin in the US and Catalonia in Spain).

\section{Methods}

We use a national informant method, in which policy experts with knowledge of their own country's child support systems are recruited to complete a detailed standardized questionnaire. This is a method that has been used successfully in the past in this policy area (Corden, 1999; Skinner et al., 2007, 2012). It differs in important respects from comparative documentary analysis or comparative analysis based on data generated by administrative institutions or government departments as it generates new primary data provided by informants. This means it is qualitative data and the elements that we examine here are based on informant's assessments of their systems regarding policy objectives and operations. 
Our analysis, therefore, does not attempt to systematically capture all objectives, functions, rules, and regulations that might operate in the different child support systems. That is because such an approach would not only require the collection of detailed (and expensive) data from a range of different institutions within and across countries (courts, enforcement agencies, child support agencies, local welfare intuitions, and social security systems) but even then still might not give an indication of the relative importance of policy principles within each country.

We report the findings on the basis of the emergent policy principles arising from our comparative analysis of informants' accounts of their systems. It is informant's perspectives that are being analyzed here, valuable in their own right as they provide an insider view. However, that is both the strength and weakness of this method. We gain deeper insights from an insider interpretation of the policy framework, but this is highly dependent upon the informant's own perspective, their level of knowledge, and the quality of their assessment of their systems. It should therefore be regarded as a complementary method to other forms of comparative analysis of child support systems rather than a substitute for them.

Mostly we recruited one national informant for each country, many of whom were academics that had earlier experience in similar research studies either acting as informants, or were involved in collecting or analyzing data in previous comparative studies on child support, or were recruited based on their earlier contribution to the field. As each informant was an expert in the field of enquiry in their own country, it eased the task of data collection and validation. Data was collected at the end of 2017 and involved national informants from 15 countries and therefore a key strength of the study is the diversity and range of child support systems there-in, covering Europe, the US (the state of Wisconsin), Australia, and New Zealand. Among other things in the questionnaire, informants provided information on child support policy, the main operational aspects of their systems, a description of the main policy principles and how these changed over time since 2006.

We begin presenting our findings with an up-to-date overview of current child support systems followed by an analysis of the policy objectives as reported from the national informant insider perspective. We use their answers to the first part of the questionnaire. First, we describe the policy principles based on our analysis of the emergent themes arising out of the informant reports. We identified four themes which we have grouped under the broad heading of "child's rights and enforcement." Second, we provide an analysis of informants' accounts where they spontaneously mention gender equality as being important, or where the recognition of paternal care and 
maternal earnings/incomes in calculating child support amounts is considered of importance. This focus helps us address the question of how and whether child support systems are regarded as responding to social changes such as greater gender equality in the parental sharing of work and care responsibilities. This part of the analysis however has limitations as there was no explicit question asking informants to comment on whether systems had become more gender equal. We therefore rely on informants raising this as an important issue in either of the two ways we have just described.

\section{Overview of Child Support Systems}

In an earlier comparative study on child support systems, Skinner et al. (2007) analyzed some key aspects of the systems across 14 countries and grouped them according to where the locus of responsibility lay for determining the child support amounts to be paid by non-resident parents. Three main types emerged: agency-based systems, court-based, and hybrid systems (in which the courts or another agency/institution could also get involved in calculating amounts). We have followed the same approach here and in Table 12.2 present an overview of the current systems grouped into these three types. It is important to note that parents can also make private agreements in all countries and while this represents a common basic principle, parental agreements are not always officially ratified or may have specific conditions attached if a parent is in receipt of social assistance benefits. Because private agreements are a common option in all countries, we consider the typology as being based on agreements relating to the formal system rather than on purely private agreements. Such formal arrangements may often mean they occur where parents cannot agree private arrangements between themselves.

Table 12.2 shows that five countries operate a primarily agency-based national system (Australia, Denmark, New Zealand, Norway, and the UK). Of the five agency systems, only Denmark and Norway offer a guaranteed amount of child support which is paid in advance by the state and is usually claimed back later by the state from the non-resident/liable parent. Such guaranteed schemes are common in Nordic and European countries (nine of our countries offer this), whereas none of the four English speaking countries offer such schemes.

Five countries and one region mainly use court-based systems to determine support amounts (Belgium, Estonia, France, Germany, Poland, and Spain [Catalonia]). These systems are characterized as discretionary and in most 


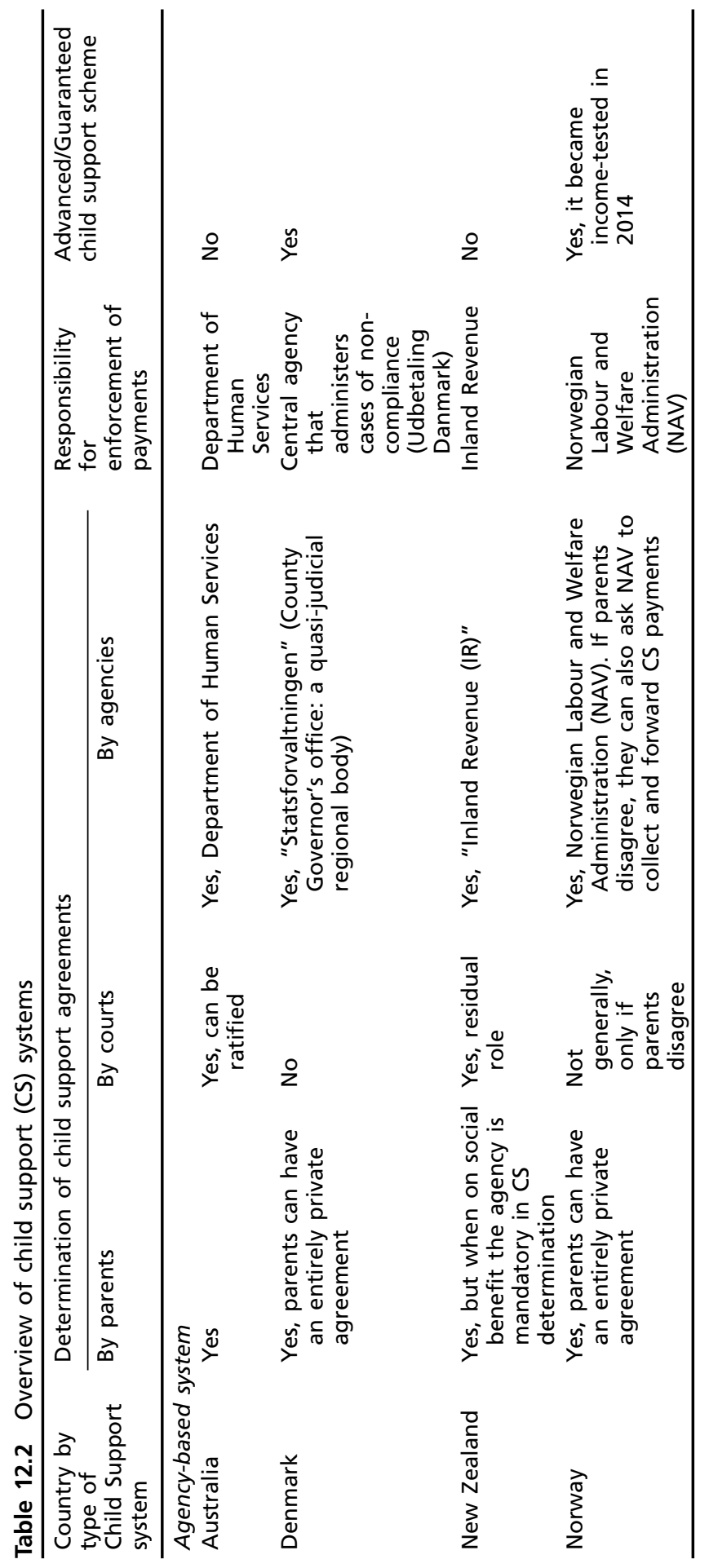




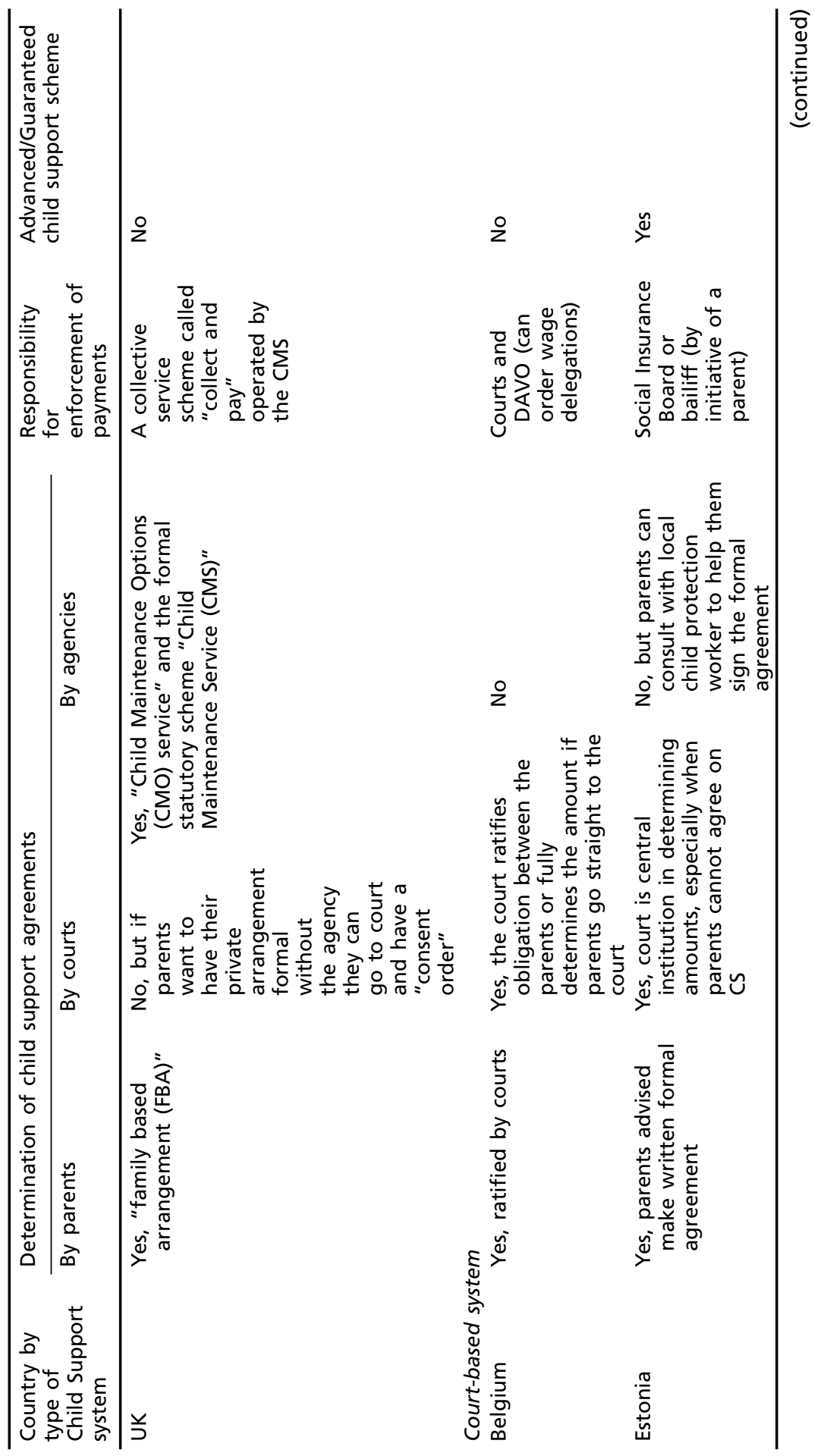




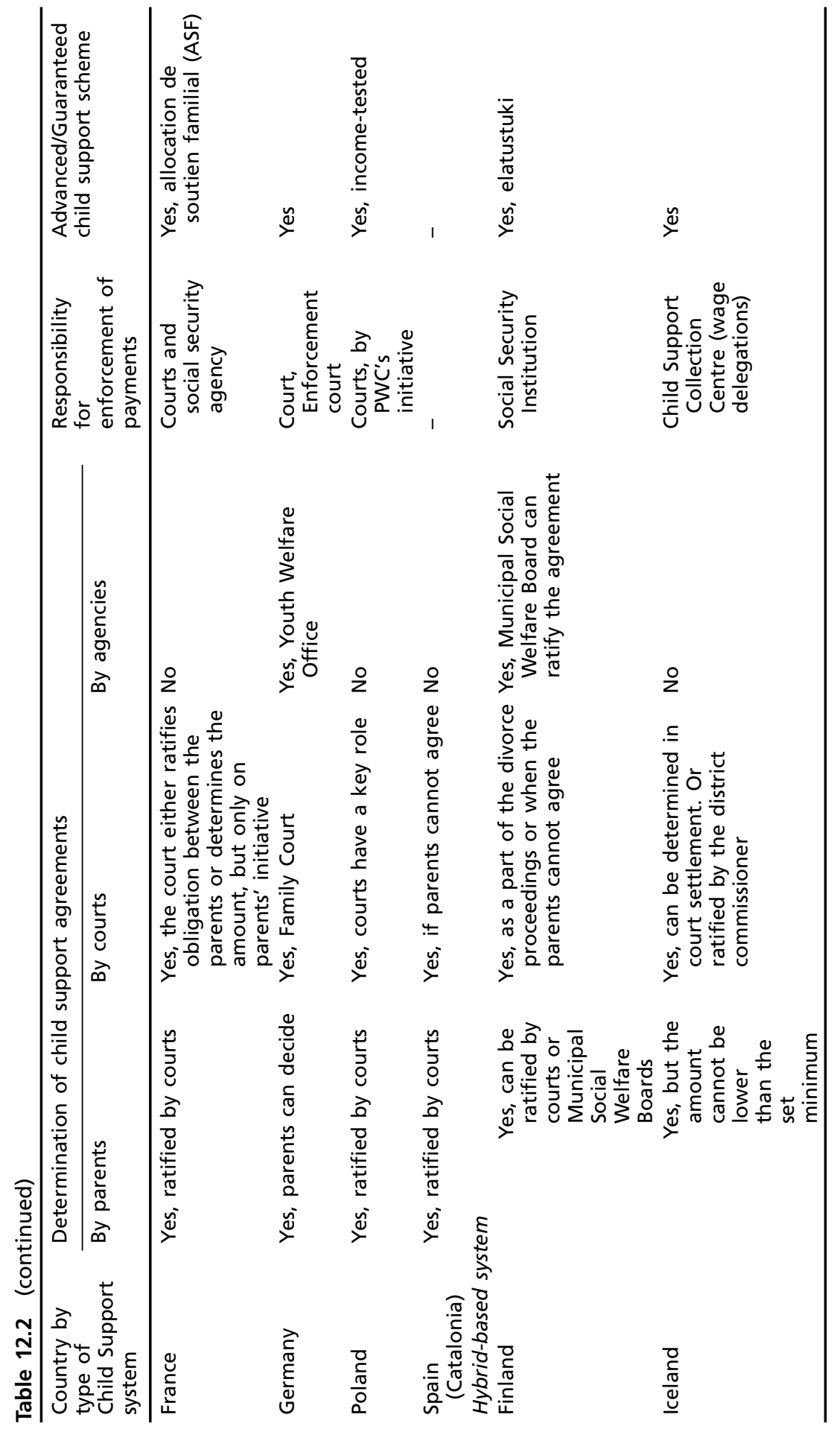




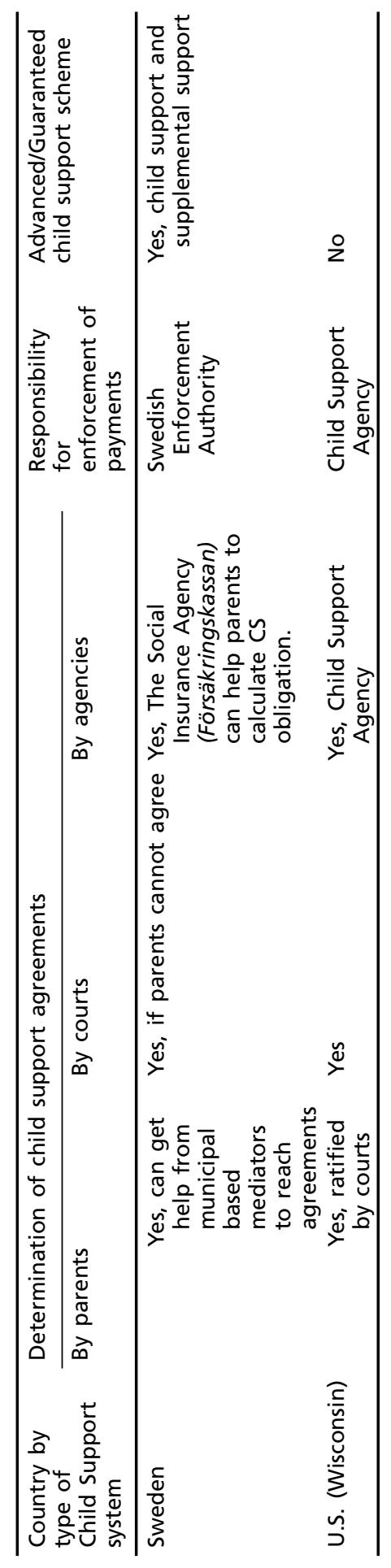


cases, they are less likely to apply standard rules and formulae when working out support liabilities. In some of these countries, various agencies may also be involved in enforcement where there is non-payment (Dienst voor Alimentatievordering [DAVO] in Belgium; Social Security Agency in France), but generally these agencies are not involved in calculating the level of the original liability. Hybrid systems on the other hand operate where there is more than one locus of responsibility in setting support amounts in formal agreements; three countries and one state (Finland, Iceland, Sweden, US [Wisconsin]) involve courts and other agencies.

This overview provides the most up-to-date comparative analysis of the key institutional characteristics of child support systems from an insider perspective. This is important new data and we use it here to set the context for our analysis on emergent policy principles underpinning these systems, to which we now turn.

\section{Policy Principles}

In this section we describe the informants' accounts of the original policy principles (the explicit or implicit policy goals) that operated in child support systems before $2006^{1}$ and the current objectives they have identified as being important in 2017. A lot of policy activity has taken place since 2006 and the data is presented in Table 12.3. Somewhat uniquely, Iceland reported no changes since 2006 and was therefore described as being policy inactive. The first column is a summary of the data as reported by informants. The second includes emergent policy principles as identified by the authors in their interpretation of the informants' reports of policy objectives operating prior to 2006. The last two columns report changes since 2006, firstly presenting informant's views followed by the authors' interpretations of emergent policy principles arising from that. ${ }^{2}$ For ease, we keep the countries organized in Table 12.3 by the three types of child support systems (agency, court, and

\footnotetext{
${ }^{1}$ This is the date Skinner and colleagues (2007) collected data on change in child support systems, so this new study here in 2017 provides some chronological continuity.

${ }^{2}$ For the purposes of completeness, Table 12.3 also identifies some of the key administrative changes as reported by informants. This serves to describe some of the policy context and is not part of the analysis per se, suffice to say that in 2017 many countries were attempting to make their systems simpler, more transparent and efficient (UK, Denmark, Belgium, Estonia, France, and Spain [Catalonia]). Finland, France and Denmark also reported administrative changes that involved more centralization or standardization occurring over time and the UK moved toward greater privatization whereby all parents were now free to make their own arrangements outside the formal system (although note Norway had also privatized their child support system in 2003). Sweden and France seemed to be working on the complex balance and interaction between publicly funded social security benefits and private child support payments.
} 


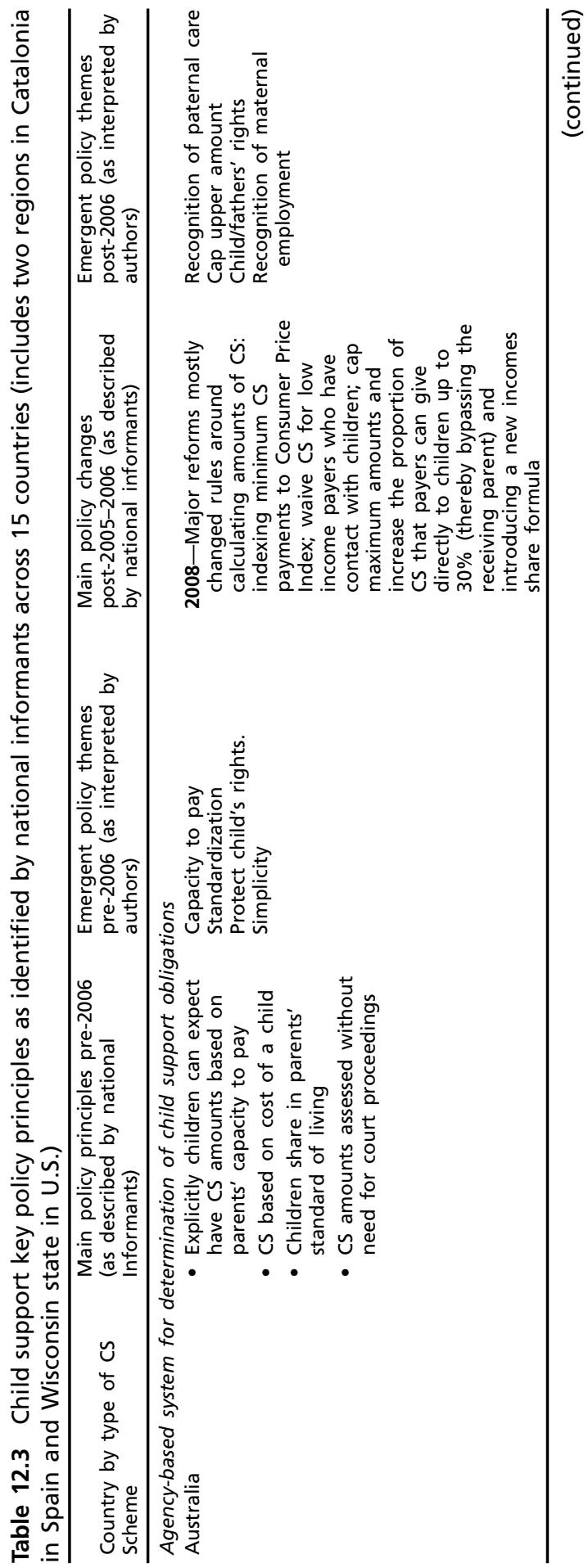




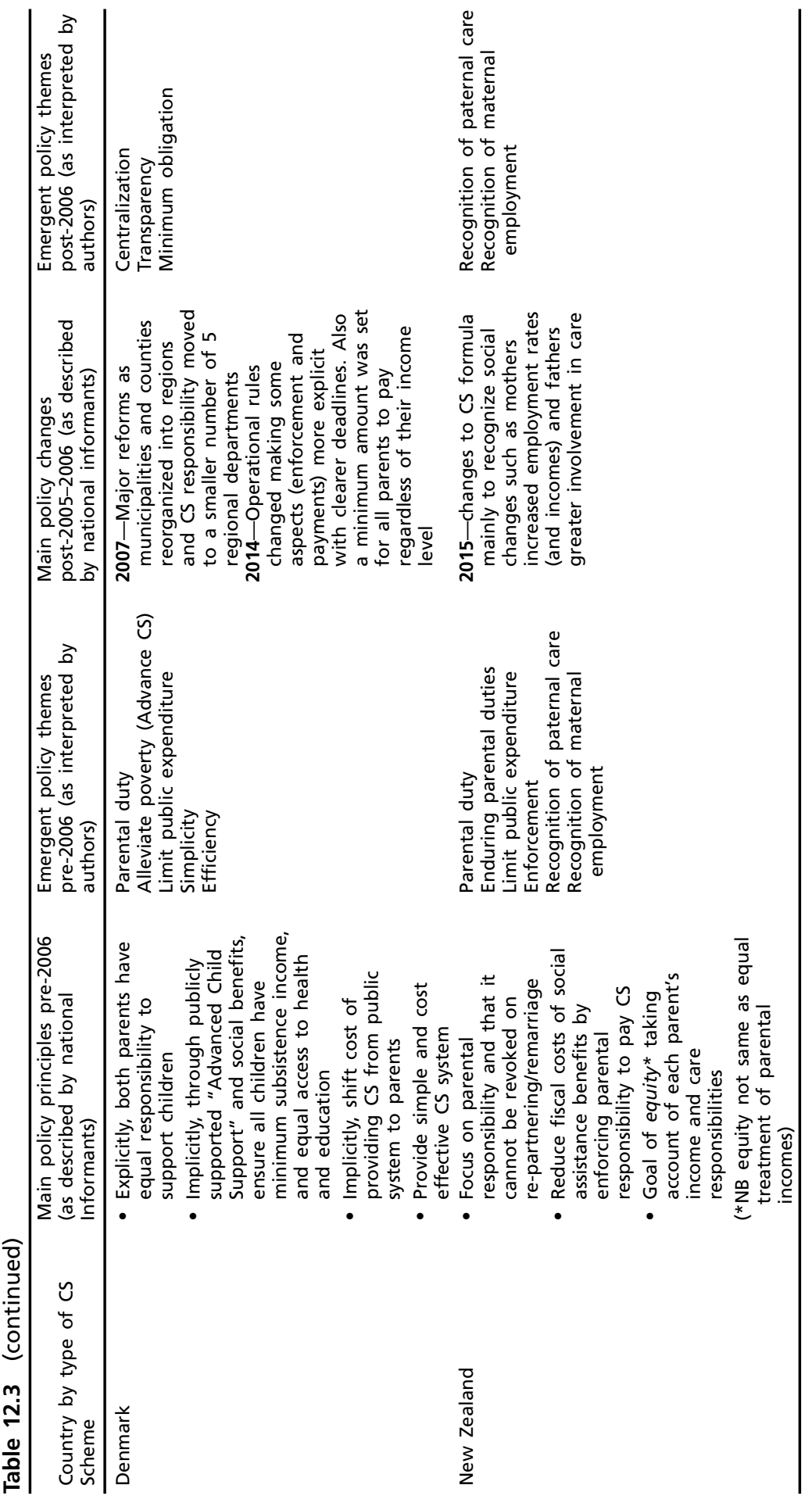




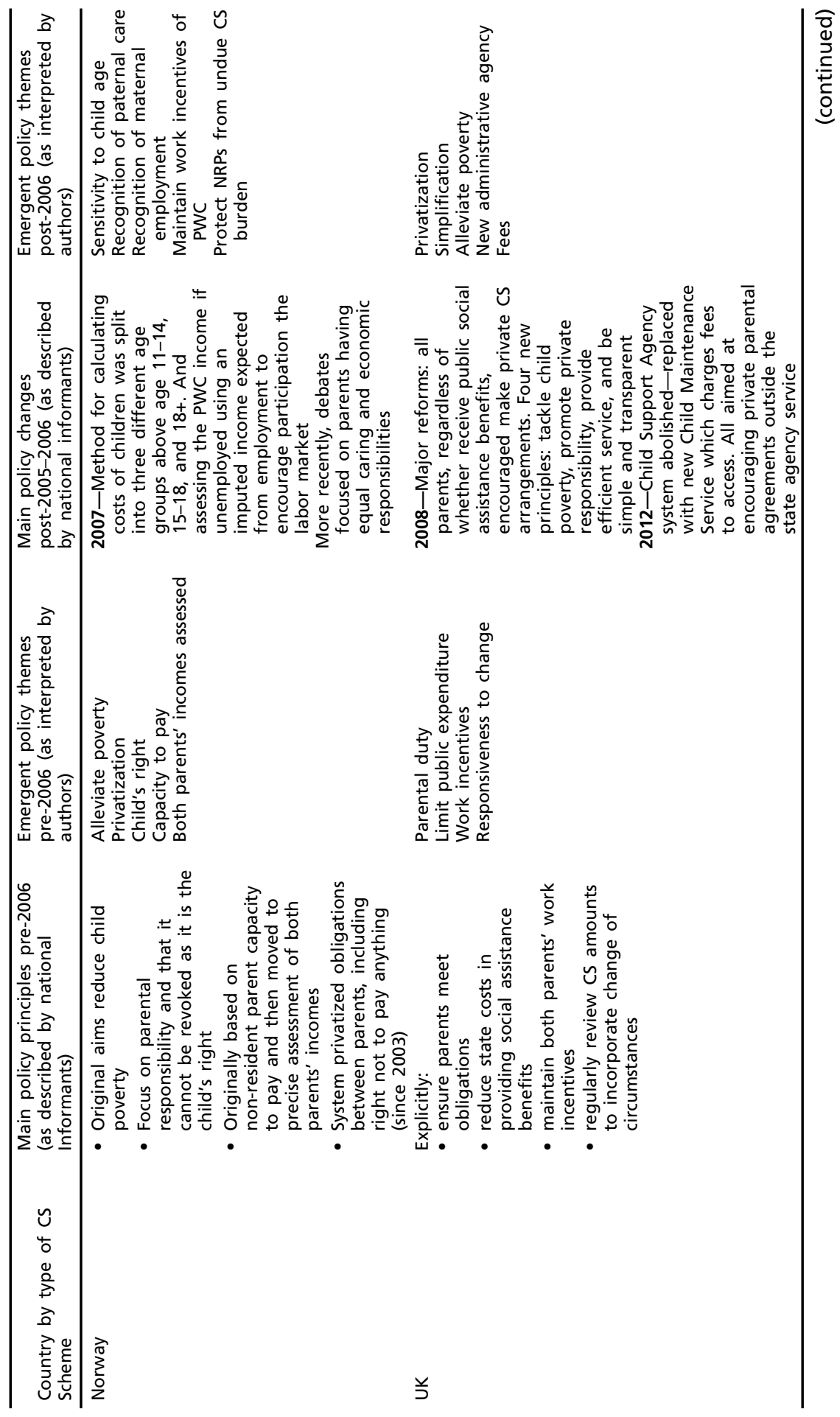




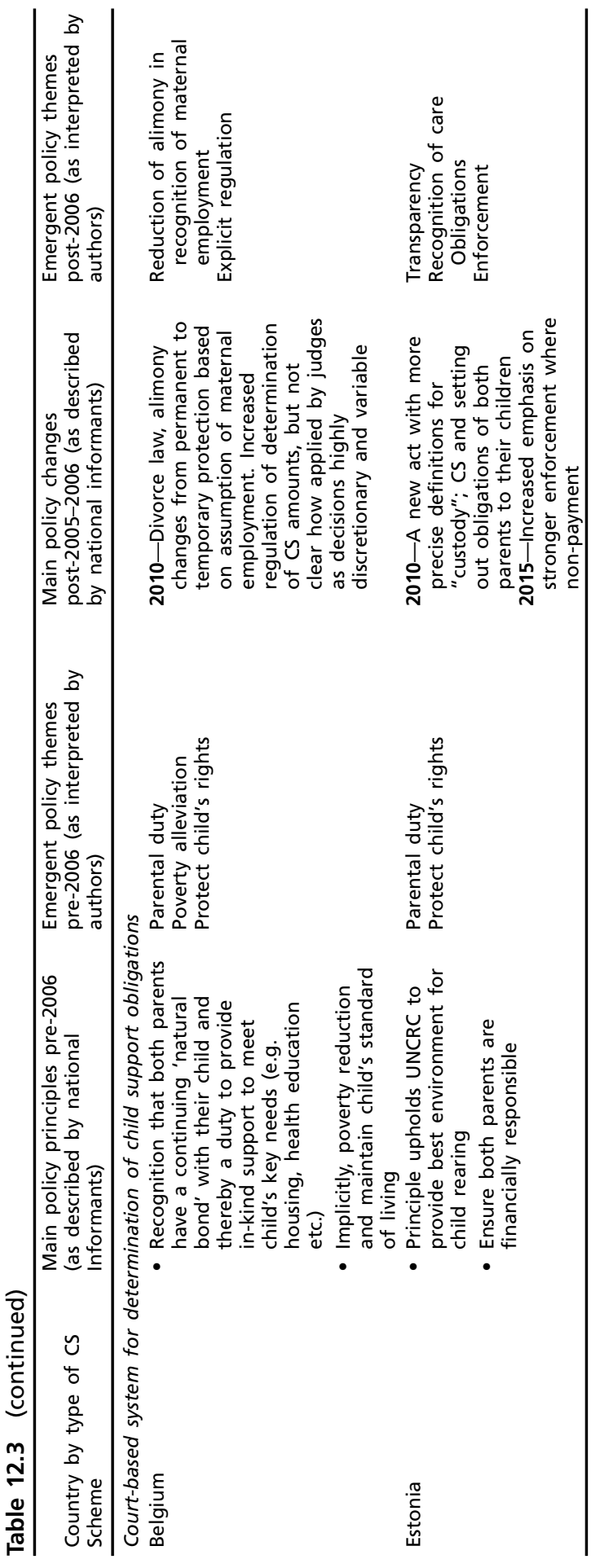




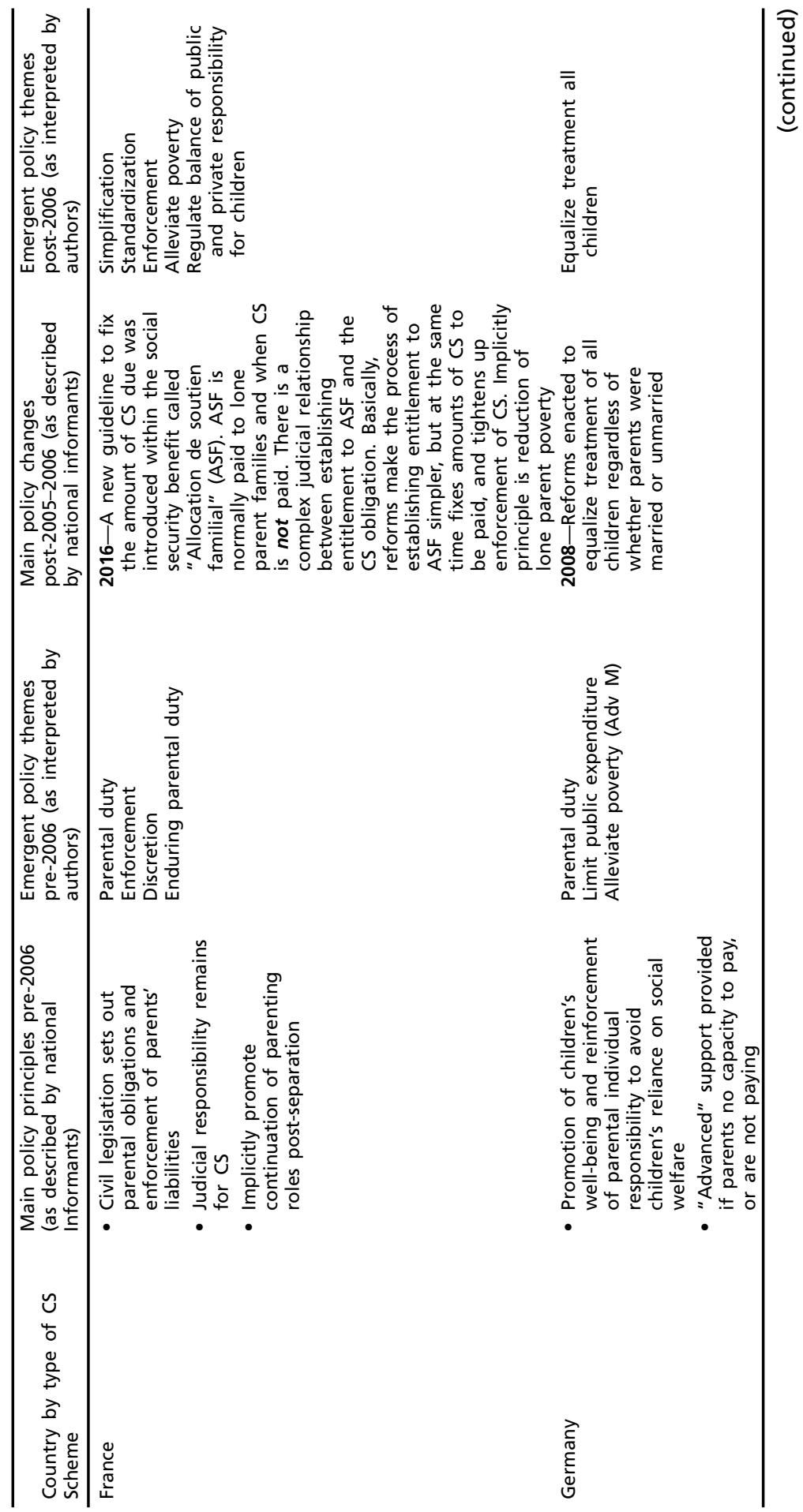




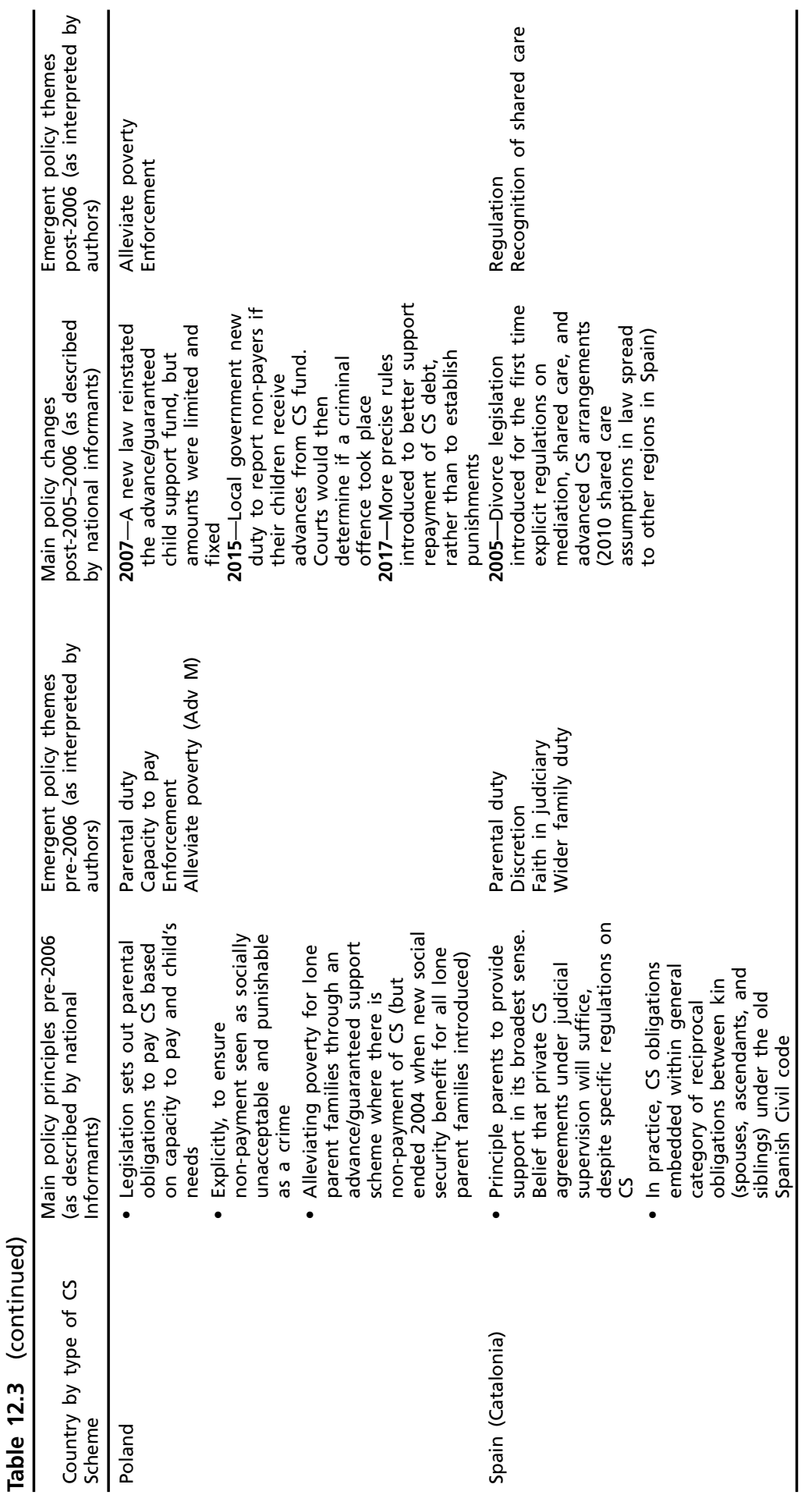




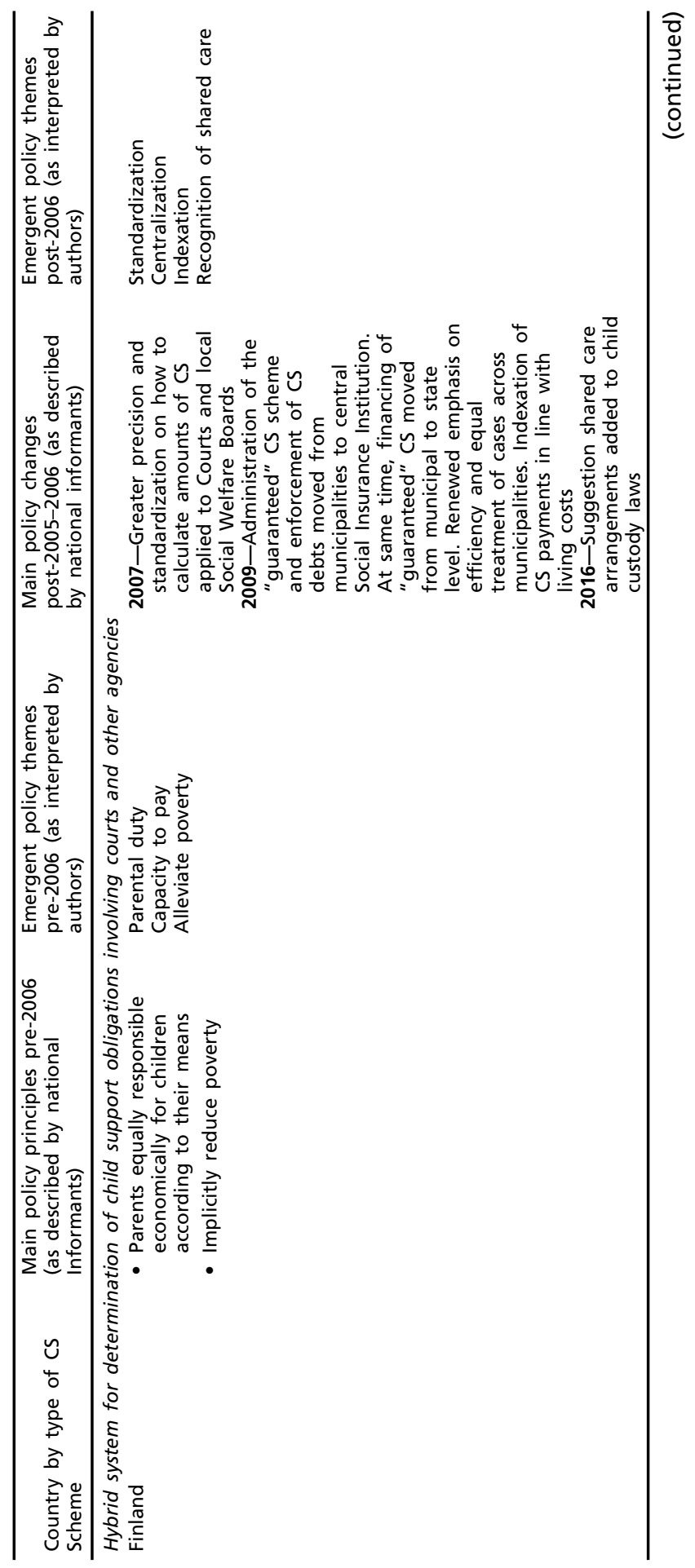




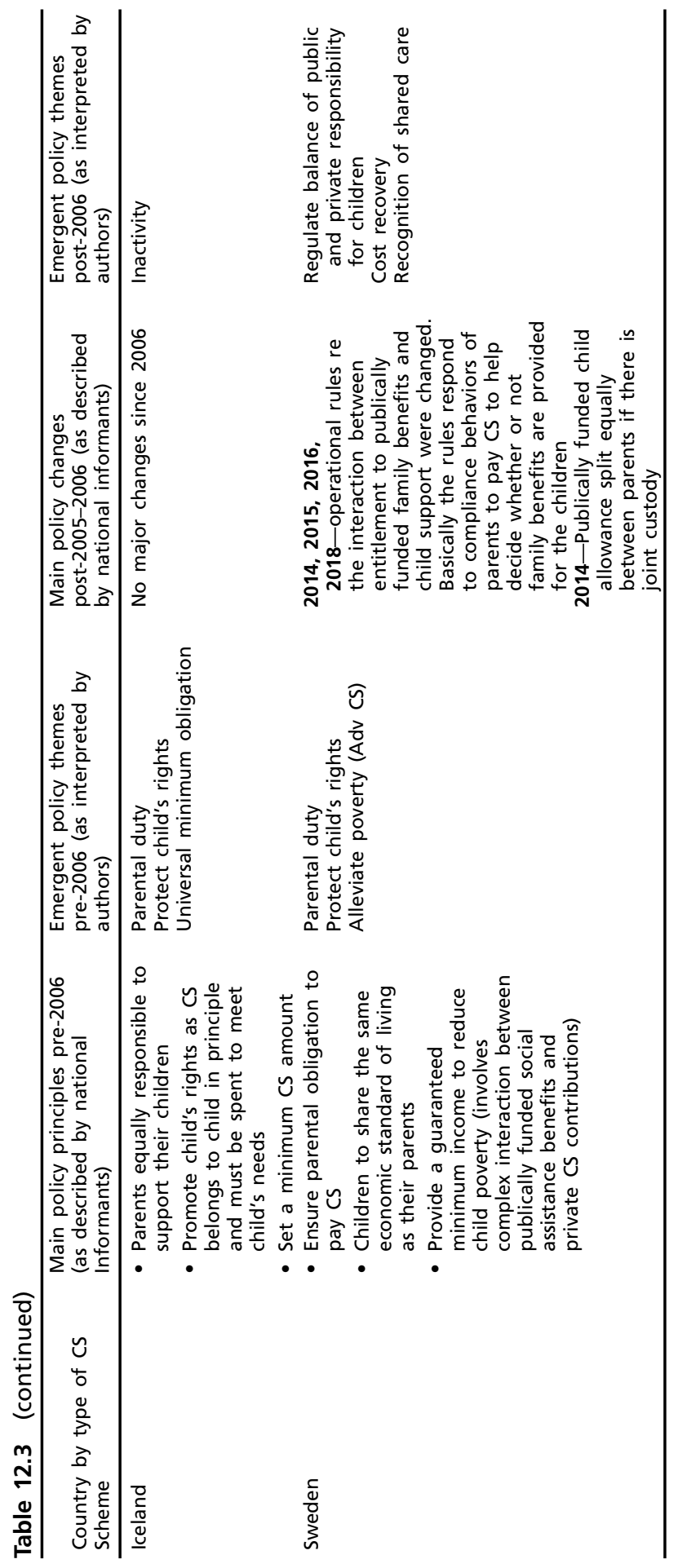




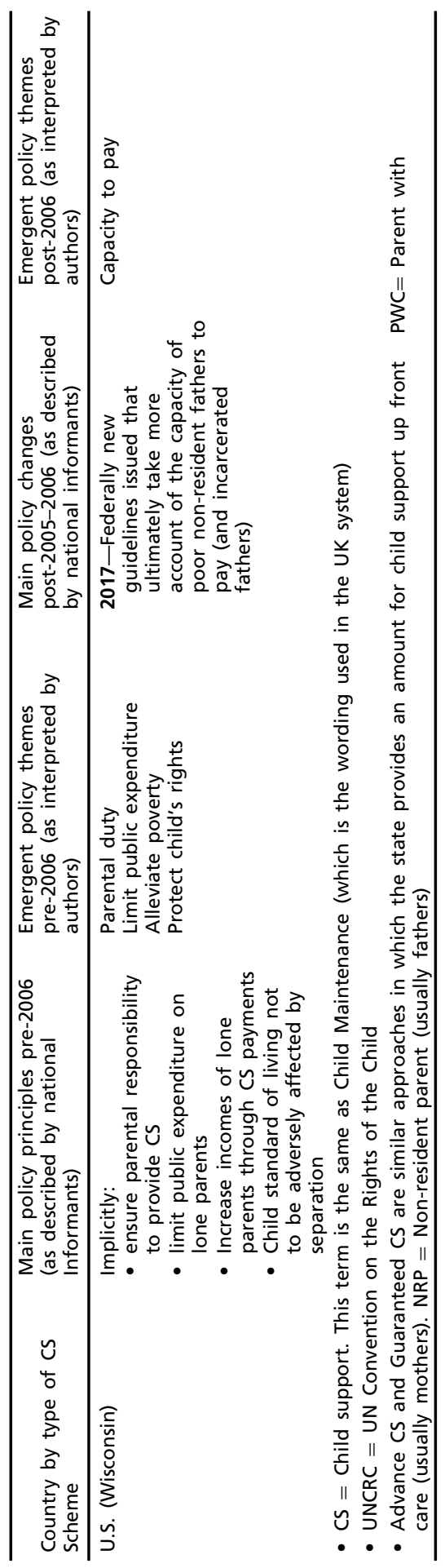


hybrid). We show these two perspectives (the informants' accounts and the authors' analysis of emergent themes arising from those accounts) to enhance the rigor of the analysis and to be as transparent as possible. In the text however, we only discuss the findings of the emergent policy principles in detail.

The set of emergent policy principles are grouped under the broader theme of "child's rights and enforcement" and these are: parental duty, child's rights, poverty alleviation, and enforcement. We discuss these first before moving to our analysis in the next section which explores whether systems are reacting to social change and perceived trends in greater gender equality in parenting.

\section{Child's Rights and Enforcement}

\section{Parental Duty}

Parental duty is the most common policy principle identified across all counties as occurring within the original manifestation of child support systems, such as where a "legal duty or obligation" is set for separated parents to continue to support their children post-separation. Some country informants specify the exact nature of parental duties as being split into health, education, and finances while others are less specific. Two informants (Norway and New Zealand) noted that the principles stressed the permanence of the parental duty; that it could not be revoked by parents' remarrying or repartnering. Germany noted that since 2008 all children were now treated equally, regardless of their parent's marital status (previously children were treated differently depending on whether their parents were legally married or cohabiting). Germany was exceptional among the countries studied here, but is now aligned in treating the parental duties of all types of parents equally.

\section{Child's Right}

In regard to child support being a child's right this was explicitly identified in seven countries (Australia, Belgium, Estonia, Iceland, Norway, Sweden, and the US [Wisconsin]), but generally only in the original manifestation of the systems. It was not mentioned as an important policy change or principle post 2006. Even so a child's right was captured in a number of different ways including: through direct reference to upholding the UN Convention of the Rights of the Child (Estonia); through the use of assessment tools that based child support calculations on the cost of a child standard (Australia); 
or through the principle that children's "standard of living" should not be affected by separation U.S. (Wisconsin), that their living standard should be maintained (Belgium) or that the children had a right to share in their parents' standard of living post-separation even if that standard increased (Sweden and Australia).

There are subtle differences across the principles with regard to a child's standard of living: one that aims to tie a child's right to a standardized "cost of the child" assessment; one that aims to protect children from a fall in their living standards post-separation; and another that enables them to share in any future prosperity of their parents. There was also a small set of changes that did occur post 2006 that could be regarded as relating to maintaining a child's standard of living; index linking child support payments. This was mentioned in Australia, where the minimal amount of child support was index linked to the Consumer Price Index and in Finland where all child support was index linked to living costs.

Another aspect of policy that might relate to the principle of ensuring a child's right, is setting a universal minimum amount of child support. This was mentioned by Iceland as an original principle pre-2006 and also that child support belonged to children; the parents were expected to spend it only on children. In relation to a child's right to have the child support spent on them, Australia also discussed how changes post-2006 increased the proportion of child support children could receive directly from the paying parent (up to nearly a third of the child support). This principle of direct pay to children could conceivably relate to theories of the "new sociology of childhood" in which children are seen as independent actors and capable of taking charge of their own support money. Alternatively, it could be argued it is a means by which fathers can bypass mothers' control over the spending of child support. This is something that fathers in Anglo-Saxon countries have raised concerns about (Cook \& Natalier, 2013; Skinner, 2013). In any event, this analysis demonstrates a range of ways that a principle of a "child's right" could be manifest and regarded as important. This is different to another policy principle that emerged from the data, that child support should alleviate poverty.

\section{Poverty Alleviation}

Poverty alleviation emerged as an important early policy principle and was described in different ways by eight informants as being part of their child support systems before 2006 (Belgium, Denmark, Finland, Germany, Poland, Norway, Sweden, and the US). For some it was described as an 
explicit policy goal and for others it was more implicit. A key aspect of child support systems was the operation of advanced or guaranteed support. Among these eight countries, all but the US and Belgium operated such schemes. All the Nordic countries mentioned it in relation to poverty alleviation (bar Iceland, which did not, although it too has a guaranteed support scheme). The guaranteed/advanced schemes operated in a range of different ways: it could be universally available to all parents with care who claimed it, or available only to single parents with care; it could be for a flat rate amount or means tested. There is not enough scope here to describe the specifics of different schemes; suffice to say, they were mentioned by some informants in relation to a principle of alleviating poverty pre-2006 and were most common in Nordic countries. Finally, of interest is New Zealand, in which poverty alleviation was said never to be a goal of the child support system, but rather the goal of welfare benefits and tax credits. So here is one country at least, where the principle of poverty alleviation was reported as not belonging to child support policy.

For policy changes post-2006, three informants mentioned that poverty alleviation was an important principle (the UK, France, and Poland). This does not mean to say it was unimportant in other countries, but from the insider informant perspective it was not mentioned as salient currently. For Poland however, poverty alleviation was highly important both pre- and post2006. As the informant explained, this was because Poland tried to abolish their guaranteed support scheme in 2004 replacing it with a new social security benefit for single parent families. However, after "mass social protests from a new social movement of single mothers" it was reinstated in 2007, although in a much more limited way than previously.

Clearly for Poland, poverty among single parent families was highly politicized. For the UK and France however, poverty alleviation seemed to emerge mostly as a principle post-2006. In France, it emerged implicitly as a result of complex changes to the ways in which single parents' entitlements to social security benefits were established and in turn how this interacted with "fixing the amounts" of child support. The informant notes there is not enough information about the payment of child support in France, and since 2016, the authorities have become more interested in improving effectiveness of policies to alleviate poverty in single parent families. In contrast in the UK, poverty alleviation was not an explicit policy objective when the Child Support Agency (CSA) was set up in 1993 (though it was widely regarded as being implicit). It was not until 2008 did it become one of four explicit objectives following major reforms which replaced the CSA and returned 
child support obligations back into the hands of parents. Ironically therefore, the state made an explicit claim of poverty reduction at a time when it withdrew from taking responsibility for ensuring child support was paid. This highlights how policy principles are differentiated from policy operations and how they can be inconsistent with one another. We note, however, that some country's child support systems are better than others at helping alleviate child poverty. We briefly discuss that evidence here.

Evidence from other comparative studies shows that child support is associated with a decrease in poverty among single mother families within a variety of countries; that is when it is paid (Cuesta, Hakovirta, \& Jokela, 2018; Hakovirta, 2011; Hakovirta, Meyer, \& Skinner, 2019). For example, in the UK and Australia child support payments reduced poverty among single mother families, respectively, by 14 percentage points and 21 percentage points (Skinner, Cook, \& Sinclair, 2017). In attempting to reduce child poverty however, one key problem for child support systems is dealing with non-compliance because failure to do so can reduce the effectiveness of child support. Certainly, not all eligible single mothers receive payments from the other parent. The highest rate of receipt is in countries where the state guarantees child support when the non-resident parent does not pay. Comparing Finland's system (which has a guaranteed scheme) with the UK and the US helps demonstrate this. In Finland $77 \%$ of single mothers received child support in 2013, but in the UK and the US only one third did (Hakovirta et al., 2019). Yet, even if compliance rates are high, another hidden problem has recently come to light which shows how the anti-poverty effectiveness of child support is disrupted by the interactions between child support payments and social security benefits (Hakovirta et al., 2019; Skinner et al., 2017).

The effects of the interactions mean that in some of the 15 countries discussed here, we know that child support payments are treated as a substitute for social security benefits leaving single parents no better off financially. This is because the state recovers the child support money through various mechanisms, effectively capping single mothers' incomes at the level of the social security benefits they receive. This capping effect appears to operate in New Zealand when assessed using model families (Skinner et al., 2017) and for Finland and Germany when assessed using Luxembourg Income Study (LIS) data on actual recorded child support payments in real families (Hakovirta et al., 2019). In contrast, the UK stands out as it treats all child support payments as a complement to social assistance benefits, meaning it can act as a top up to single parent incomes above social security benefit levels, but note only if it is paid (Hakovirta et al., 2019). Similarly, in Australia single parents can keep nearly all of the child support, again if it is paid (Hakovirta 
et al., 2019). Therefore, while poverty alleviation is an important policy principle and operationally some countries child support systems appear to be more effective than others, we can see that enforcement could be an integral part of poverty alleviation and an important part of maintaining child rights.

\section{Enforcement}

Only three informants however, emphasized enforcement as being particularly important (France, Poland, and Estonia). For France looking at the changes over time pre- and post-2006, enforcement was described as being originally set within the civil legislation to uphold parents' liabilities. Whereas in 2016 the emphasis changed; enforcement also became part of the social security benefit reforms mentioned earlier under poverty alleviation. The social security system was now able to enforce "simple" child support agreements made between parents. So again, for France we see how child support obligations interacted in complex ways with social security entitlements, especially for poorer single parent families. It seemed however, that despite the complexity, they were trying to find better ways of enforcing payments.

Similarly in Poland, the child support system emphasized enforcement as an explicit policy principle, though perhaps in stronger terms than reported in France. From its inception, the child support system reportedly set out to make non-payment "socially unacceptable," making it a criminal offense to not pay. Later, a new act in 2015 required local authorities to add the names of non-payers into a "National Debt Registry" to better enforce prosecution. However, the wording of the act was amended in 2017 to ensure that non-payers were given the chance to pay off their debts, rather than be fined, or imprisoned as the first course of action. For Estonia, debates regarding improving enforcement measures arose more recently in 2008 and were reemphasized by the new government in 2015 . New policy measures ensued and in 2016 penalties for non-payment (such as revoking certain licenses for hunting, driving, and gun ownership) were increased. Additionally, bailiffs were given greater powers to remain in contact with non-payers so assets could be seized should they persistently not pay. Overall, France, Poland, and Estonia appeared to share similarities: all three were court-based systems and the policy emphasis shifted toward encouraging payments, rather than simply punishing non-payment (especially evident in Poland).

In sum, the analysis highlighting emergent policy principles across countries are all acting to protect children's rights, in one way or another. But we found other sets of principles which related more to how systems dealt 
with parental responsibilities in terms of recognizing paternal care/shared care arrangements or maternal employment or incomes. To which we now turn.

\section{Gender Equality}

As discussed above, one of the key aims of the analysis of this comparative data was to ascertain whether key social changes in families, such as greater equality in parenting responsibilities, were being reflected in child support systems. Certainly, gender equality is manifest in calls from separated parents and others for more equal "joint physical custody" arrangements post-separation (Hakovirta \& Skinner, 2021). However, informants were not directly asked about gender equality. We have therefore used any explicit mention of gender equality (where it occurred spontaneously in responses in the first part of the questionnaire) alongside our analysis of informants' reports on the importance of systems taking account of shared care/paternal care and mothers' employment/incomes in determining child support liabilities.

\section{Recognition of Paternal Care}

When informants were asked to describe the main policy principles of their systems, a few explicitly mentioned gender equality as being particularly important. As shown in columns three and four in Table 12.3 these countries were Australia, New Zealand, and Norway. Overall six informants mentioned recognition of paternal care/shared care as being an important policy principle. This recognition occurred more often after 2006. For example, only New Zealand and Norway mentioned paternal/shared care as important both pre-2006 and post-2006, and four other countries mentioned it only after 2006 (Australia, Estonia, Finland, Spain [Catalonia]).

New Zealand reported having an original policy goal of equity between parents in which paternal care was recognized and this was later strengthened following public consultation and the development of a new act in 2013. This act altered the child support formula to reflect the apparent increase in care contributions made by separated fathers, but it also recognized the rising rates of maternal employment (discussed further below). Similarly for Norway, they strengthened their position of treating mothers and fathers equally post2006 (see discussion on maternal employment below). In Australia, major reforms in 2008 reportedly emphasized fathers' contribution to care more strongly and indeed waived child support liabilities for low income fathers 
who remained in contact with their children post-separation. Reforms also recognized the increased participation rates of mothers in the labor market (discussed below). In Estonia's court-based system, paternal care recognition was said to occur within a legal framing, with the introduction of a new family law act in 2010 stipulating more clearly the definition of custody and the obligations of both parents to care for their children. In Finland suggestions were made in 2016 that shared care arrangements be added into child custody laws. Whereas for Spain (Catalonia), assumptions around shared care were introduced for the first time in divorce legislation in 2005 and while it was thought this would have little effect, a legal presumption of shared care spread across a number of northern regions in Spain with new laws enacted in 2010.

What emerges from these accounts is differences in the way informants in the six countries talked about recognition of paternal care, with those in Court or hybrid systems (Estonia, Finland, and Spain [Catalonia]) tending to refer to debates around "custody" and shared care within family law. Whereas in New Zealand, Australia, and Norway these are agency-based systems, and these informants tended to report changes in the child support formula made to better recognize paternal care. Either way, recognition of paternal or shared care has been reported as an important part of the policy principles either as a source of debate, or of policy change in child support systems for six of the fifteen countries. This indicates at least some recognition of changing social norms and associated trends in gender equality. Closely related to recognition of paternal care, is recognition of mothers' increased capacity to have independent incomes through paid employment.

\section{Recognition of Maternal Income and Employment}

As mentioned above, gender equality was a strong principle mentioned explicitly only in informants' accounts from Australia, New Zealand, and Norway, though there were differences. In New Zealand, it seemed they adopted a principle of gender equality early on, whereas in Australia it was embedded in debates that took place around the 2008 policy reforms. Policy debates in Australia acknowledged mothers' increased participation in the labor market, and the possibility at least, of mothers gaining independent incomes from earnings. This resulted in mothers' incomes being included in a new "incomes share" formula for calculating child support. It is important to note at this point that other countries may also have counted mothers' incomes in their calculations, but what we are reporting here are the 
informants' perspectives of their main policy objectives and not providing a detailed administrative account of all operational features.

In Norway too, gender equality was mentioned as a strong principle in regard to the acknowledgment of trends in maternal employment; policy debates there focused on separated parents both having equal care and equal financial responsibilities. Norway has taken this principle further by using child support policy to manipulate parental behaviors in the labor market. For example, the informant reported that when calculating child support, if the mother is unemployed, an "imputed" earnings figure is applied to the child support calculation and this is done to encourage her participation in employment. But it is also done to protect fathers from having "undue" support costs being passed onto them as a result of mothers choosing to "opt out" of the labor market. This implies that the movement in and out of the labor market for separated mothers in Norway is seen as a free choice they can make. Whether or not this policy assumption reflects the reality of Norwegian mothers' capacity and freedom to enter the labor market, it is important to note that Norway has a largely privatized child support system and parents can agree to have no child support arrangement if they so wish. So, gender equality based principles (and related operational tools) are only applicable when separated parents choose to use the formal system (for which they pay a fee) or where the parent with primary care seeks guaranteed child support from the state. But what does all this mean? What can we say about gender equality and child support systems? We now discuss that in our conclusion.

\section{Conclusion}

Overall, we found that broader social changes for greater gender equality in the division of labor in families are not reflected very much in child support systems over the last 10 years (2006/7-2017). Among the fifteen countries studied here, only in Australia, New Zealand, and Norway, did gender equality emerge in informants' accounts as an important policy principle, or as an important part of debates in child support policy reforms. All three countries have agency-based systems and this may be an important factor, possibly because they tend to operate more explicit rules and formulae in calculating child support liabilities. Thereby decision-making is made more transparent potentially rendering these systems more susceptible to greater scrutiny regarding the gender equal treatment of both parents' incomes (Cook \& Skinner, 2019; Skinner, 2013). However, it is interesting to note from other research that the remaining two agency-based systems (UK 
and Denmark) do not count mothers' incomes in calculating child support amounts (Hakovirta \& Skinner, 2021). Arguably therefore, they are more attached to a traditional male breadwinner model of separated families, highlighting there is little recognition of changing social norms as of yet, at least in terms of recognizing parental earning capacities.

Using the new data in the study reported here, we cannot be sure however whether assumptions of a male breadwinner model operate in the court and hybrid child support systems. Partly because these systems tend to operate more discretionary decision-making procedures when setting child support liabilities. In that regard, three informants from Estonia, Finland, and Spain (Catalonia), did note that while policy discussions had taken place in their countries around giving greater recognition to paternal care, this mostly occurred within a broader family law frame than in the operation of child support systems per se (for example, in divorce and custody arrangements post-separation). So, equality in care time at least, may become a more important policy objective in the future.

Certainly, our analysis is exploratory and has limitations regarding the type of data collected using a national informant method and questionnaire format. Even so, it seems that from the informants' reports on the policy principles, there is little recognition of the broader social changes denoting shifts toward greater gender equality in parental responsibilities (i.e., more maternal employment and more paternal care). There might be very good reasons for this-such as policy focusing more on other key objectives of child support policy — that is to protect children's rights and alleviate child poverty. Gender equality could therefore be seen as a competing policy objective and related more to parents' interests than to protecting children interests.

Certainly, in the three countries reported here where gender equality was an explicitly recognized feature, not all their child support systems were good at poverty reduction; at least as measured in other studies focusing on single parent families. We know, for example, that New Zealand treats child support payments as a substitute for state social assistance benefits paid to poor single parent families. This means that child poverty is not reduced by child support payments in New Zealand as incomes are capped at the rate of social assistance benefits (though poverty may be reduced via social security benefits) (Skinner et al., 2017). In contrast, Australia moved to treating child support as a complement to social security benefits, thereby it topped up incomes. In theory at least, the anti-poverty effectiveness of child support payments is enhanced in Australia on this basis (Hakovirta et al., 2019). Norway is fairly unusual, parents are supported to enter into a private agreement on child support, but if they cannot agree, the parents can apply for child support to 
be established by the national social insurance institution. Even so, gender equality featured quite strongly in Norway and appeared to be based on assumptions of an adult worker model.

The findings from this new comparative study demonstrate that we have a long way to go before we can fully understand whether child support systems are adapting to perceived social changes in gender equality in the division of labor in families. Certainly, it is clear that more extensive research would be needed to address the question of whether the pursuit of gender equality in child support systems would be beneficial and to whom it might benefit, or to whom it might cause possible harm. To do so would require a full examination of child support systems, social security systems, and the interactions between both systems in terms of the poverty effects produced. But whether child support systems are, or should be, a key policy in the fight against poverty is itself a politically sensitive topic.

As we have highlighted, child support systems could face potentially competing objectives, the pursuit of gender equality (at least in terms of acknowledging an equal division of earning and caring responsibilities) is likely to be at odds with the principle that child support policy should tackle child poverty. Yet, while the traditional breadwinner model of families is in decline and families may achieve greater gender equality, the question of whether a principle of gender equality as applied to child support policies is a good thing to pursue, is one of the most difficult challenges for future family policies. Our comparative analysis makes a unique contribution to that debate.

Acknowledgment This work was supported by the Academy of Finland grant number 294648, 2016.

\section{References}

Andrews, S., Armstrong, D., McLernon, L., Megaw, S., \& Skinner, C. (2011). Promotion of child maintenance: Research on instigating behaviour change. Leeds, UK: Child Maintenance and Enforcement Commission, research report no. 1, volume I, main report, Corporate Document Centre. Retrieved April 13, 2019, from http://webarchive.nationalarchives.gov.uk/20120716161734/http:// www.childmaintenance.org/en/pdf/research/Main-Report-Vol-I.pdf.

Bianchi, S. M. (2011). Family change and time allocation in American families. The ANNALS of the American Academy of Political and Social Science, 638(1), 21-44. 
Claessens, E., \& Mortelmans, D. (2018). Challenges for child support schemes: Accounting for shared care and complex families. Journal of European Social Policy, 28(3), 211-223.

Cook, K., \& Natalier, K. (2013). The gendered framing of Australia’s child support reforms. International Journal of Law, Policy and the Family, 27(1), 28-50.

Cook, K., \& Skinner, C. (2019). Gender equality in child support policy: Fathers' rhetoric of "fairness" in a parliamentary inquiry. Social Politics: International Studies in Gender, State \& Society, 26 (1), 164-187.

Corden, A. (1999). Making child maintenance regimes work. Family Policy Studies Centre.

Craig, L. (2006a). Does father care mean fathers share? A comparison of how mothers and fathers in intact families spend time with children. Gender \& Society, 20(2), 259-281.

Craig, L. (2006b). Children and the revolution: A time-diary analysis of the impact of motherhood on daily workload. Journal of Sociology, 42(2), 125-143.

Cuesta, L., Hakovirta, M., \& Jokela, M. (2018). The antipoverty effectiveness of child support: Empirical evidence for Latin American countries. Social Policy \& Administration, 52(6), 1233-1251.

Fehlberg, B., Smyth, B., Maclean, M., \& Roberts, C. (2011). Legislating for shared time parenting after separation: A research review. International Journal of Law, Policy and the Family, 25(3), 318-337.

Hakovirta, M. (2011). Child maintenance and child poverty: A comparative analysis. Journal of Poverty and Social Justice, 19(3), 249-262.

Hakovirta, M., \& Eydal, G. B. (2020). Shared care and child maintenance policies in Nordic countries. International Journal of Law, Policy and the Family, 34(1) 43-59.

Hakovirta, M., Meyer, D. R., \& Skinner, C. (2019). Does paying child support impoverish fathers in the United States, Finland, and the United Kingdom? Children and Youth Services Review, 106, 104485.

Hakovirta, M., \& Skinner, C. (2021). Shared physical custody and child maintenance arrangements: A comparative analysis of 13 countries using a model family approach. In L. Bernardi \& D. Mortelmans (Eds.), Shared physical custody. Springer Open.

Hakovirta, M., Skinner, C., Hiilamo, H., \& Jokela, M. (2020). Child poverty, child maintenance and interactions with social assistance benefits among lone parent families: A comparative analysis. Journal of Social Policy, 49(1), 19-39.

Haux, T., McKay, S., \& Cain, R. (2017). Shared care after separation in the United Kingdom: Limited data, limited practice? Family Court Review, 55(4), 572-585.

Lyonette, C., \& Crompton, R. (2015). Sharing the load? Partners' relative earnings and the division of domestic labour. Work, Employment \& Society, 29(1), 23-40.

Meyer, D. R. \& Carlson, M. (2014). Family Complexity: Implications for policy and research. The ANNALS of the American Academy of Political and Social Science, 654(1), 259-276. 
O'Connor, J. (2013). Gender, citizenship and welfare state regimes in the early twenty-first century: Incomplete revolution and/or gender equality lost in translation. In P. Kennet (Ed.), Handbook of comparative social policy. Cheltenham: Edward Elgar.

OECD. (2019). OECD family database. http://www.oecd.org/els/family/database. htm.

Skinner, C. (2013). Child maintenance reforms: Understanding fathers' expressive agency and the power of reciprocity. International Journal of Law, Policy and the Family, 27(2), 242-265.

Skinner, C., Bradshaw, J., \& Davidson, J. (2007). Child support policy: An international perspective. Corporate Document Services.

Skinner, C., Cook, K., \& Sinclair, S. (2017). The potential of child support to reduce lone mother poverty: Comparing population survey data in Australia and the UK. Journal of Poverty and Social Justice, 25(1), 79-94.

Skinner, C., Hakovirta, M., \& Davidson, J. (2012). A comparative analysis of child maintenance schemes in five countries. European Journal of Social Security, 14(4), 330-347.

Skinner, C., Meyer, D. R., Cook, K., \& Fletcher, M. (2017). Child maintenance and social security interactions: The poverty reduction effects in model lone parent families across four countries. Journal of Social Policy, 46 (3), 495-516.

Smyth, B. (2017). Special issue on shared-time parenting after separation. Family Court Review, 55(4), 494-499.

Trinder, L. (2010). Shared residence: A review of recent research evidence. Child and Family Law Quarterly, 22(4), 475-498.

Wikeley, N. (2006). Child support law and policy. Oxford: Hart Publishing.

Open Access This chapter is licensed under the terms of the Creative Commons Attribution 4.0 International License (http://creativecommons.org/licenses/by/4.0/), which permits use, sharing, adaptation, distribution and reproduction in any medium or format, as long as you give appropriate credit to the original author(s) and the source, provide a link to the Creative Commons licence and indicate if changes were made.

The images or other third party material in this chapter are included in the chapter's Creative Commons licence, unless indicated otherwise in a credit line to the material. If material is not included in the chapter's Creative Commons licence and your intended use is not permitted by statutory regulation or exceeds the permitted use, you will need to obtain permission directly from the copyright holder.

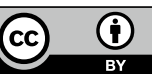

